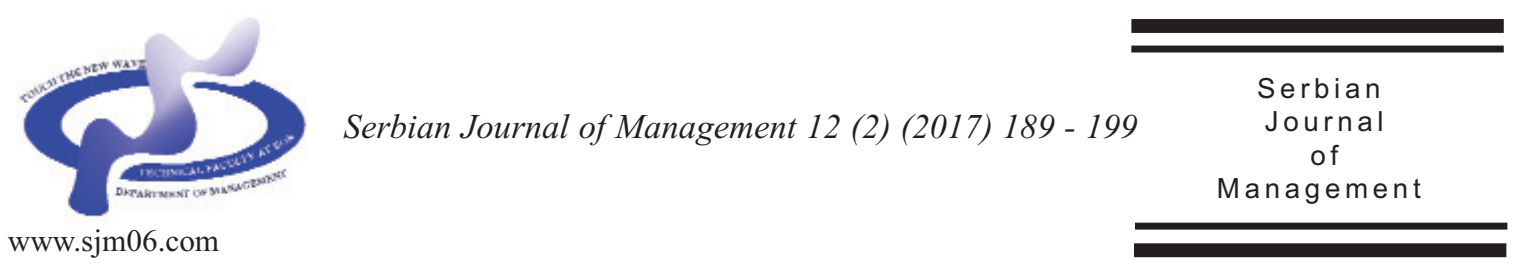

\title{
4A MARKETING MIX IMPACTS ON ORGANIC FOOD PURCHASE INTENTION
}

\author{
Bahar Türk* and Aysel Erciş \\ Atatürk University, Faculty of Economics and Administrative Science, \\ 2540 Erzurum, Turkey
}

(Received 26 April 2016; accepted 15 November 2016)

\begin{abstract}
Nutrition is one of the main factors leading to a sustainable and healthy life. Consumers generally make decisions related to their daily nutrition and food choice. Therefore, it is important to determine the main potential factors affecting the final decision. These variables, also known as the 4As (acceptability, affordability, accessibility and awareness), affect consumers' decisions in all stages of the purchase decision process. The purchase intention takes place at the beginning of this process. The determination of the most influential variable on the purchase intentions is crucial and helpful for each shareholders that concentrates on attracting consumers' decisions in the decision process. The aim of this study is to provide a better insight in green purchase intention and to find which 4A attribute is more effective on purchase intention of organic foods. For this purpose, the data were analyzed by Analytic Hierarchy Process (AHP). The data were collected from 10 experts of Aarhus University's MAPP Centre. Results revealed that "awareness" is the most effective among 4A mixed elements, followed by "affordability", "accessibility" and "acceptability".
\end{abstract}

Keywords: 4A Marketing Mix, Organic Food Purchase Intention, Analytic Hierarchy Process (AHP)

\section{INTRODUCTION}

As we all know, 4P has become a basic principle of modern marketing. But we now have a new 4A concept of recent vintage (Sheth \& Sisodia, 2012). This concept helps managers and others to see every action through the eyes of the customers. It is established on the values that matter most to customers: Acceptability, Affordability, Accessibility and Awareness. Hence, these traits are named the "4A's" (Sheth \& Sisodia, 2012).

The 4A mix has initiated discussions with new and micro perspectives such as the $4 \mathrm{P}$ mix. The green purchase process is one of

\footnotetext{
* Corresponding author: baharsturk@yahoo.com.tr
}

DOI: $10.5937 /$ sjm12-10785 
them. Zhen and Mansori's study (Zhen \& Mansori, 2012) is one of the studies dealing with this perspective. The authors found that 4A attributes have an impact on consumers' green purchase intention process.

Today, green purchase intention is one of the noteworthy purchasing processes, and in environmental protection, every consumer plays a role. The most important role of consumer in the environmental protection, makes a right choice in their purchasing process (Türk \& Erciş, 2015). Therefore, green products and green product purchase intention are a strategic matter. In this study, organic food is discussed and is considered as a green product. As a result of public interest in healthy living and organic agriculture, the notion of organic food purchasing has become very important for the food industry as well as consumers. The growing consumer interest in organic food production and consumption increase the potential impact of sustainability considerations on consumer purchase decisions (De Boer et al., 2006).

\section{LITERATURE REVIEW}

\subsection{Green Purchase Intention}

Basically, organic food can be described as an improved quality of food without any hormones, antibiotics, poisons, genetically modification or irradiation (Jones et al., 2001). The concept of food choice is a complex phenomenon that points to one of the most important parts of human life (Furst et al., 1996). Whether a consumer intents or decides to purchase organic food products is a difficult process because it depends on many factors that cannot be directly controlled (Thøgersen, 2010). Therefore, the best way to explain the difficult and complicated process is to examine the purchase intention, because the intention is the best predictor of behavior. Theory of Planned Behavior (TPB) can be used in order to evaluate and predict consumers' actual behavior and consumer intention (Conner \& Sparks, 2005; Hansen, 2008). Hence, TPB is an important theoretical method for researchers to examine purchase intention of organic food (Bredahl, 2001; Dreezens et al., 2005; Verdurme \& Viaene, 2003).

Studies show that organic products are perceived to be better with respect to naturalness of raw material, taste, quality, and safety impact on health and on the environment. However, a negative attitude is found regarding the price or affordability, appearance, accessibility and conservation (Vermeir \& Verbeke, 2008; Ploeger, 2009; Rezai et al., 2011; Shaharudin et al., 2010). Additionally, most consumers have the intention to try organic foods, but this was usually conditional upon issues of affordability, acceptability, accessibility and perceived quality (Weatherell et al., 2003; Vermeir \& Verbeke, 2006).

\subsection{A Marketing Mix}

The 4A Mix was defined in order for businesses to create customer value (Sheth \& Sisodia, 2012). But studies shows that these variables affect consumer attitudes and intentions (Vermeir \& Verbeke, 2008; Nezakati et al., 2013). Some researchers have used different names of the variables (e.g. "availability" instead of "accessibility") (Anderson \& Billou, 2007; Sarkar \& Pareek, 2013), other researchers reduced or added some variables (e.g. drops "acceptability" and adds "accessibility") (Prahalad, 2009; 2012) and still others have increased the 
number of variables (e.g. like 5 A's) (Kamande \& Jarhult, 2013). But the most detailed discussion have been done by Sheth and Sisodia (2012). They examined 2 dimensions for each of the A's as follows:

Acceptability means that the products meet and exceed the expectations of consumers. It has two dimensions: a functional acceptability and psychological acceptability (Sheth \& Sisodia, 2012). The expectations have importance when determining the level of acceptability. Knowing how someone feels about buying or using the product is more effective than just knowing the consumers' evaluation of the object itself (Ajzen, 1988). In this way, the functional and psychological expectation outcomes resulting from that behavior are an important antecedent to an intention. Additionally, acceptability is an important food choice motivation when the consumer makes decisions regarding everyday food shopping (Chen, 2007). Organic food is a more sustainable alternative than conventional food (Thøgersen, 2010) because organic food is perceived as much more healthy, natural, nutritious, and sustainable than conventional foods (Hughner et al., 2007; Yin et al., 2010). Hence, it is believed that the consumer's attitude to organic foods purchase is positively related to the attitude to organic foods. In other words, when the consumer's expectations to organic foods are positive, the consumer's expectations to organic foods purchase will be more likely to be positive. Contrary to this, when consumer's expectations to organic foods are negative, it will result in a negative attitude to organic foods purchase (Chen, 2007).

Affordability; is defined as whether customers are able and willing to pay the offered product's price. This also includes psychological (willingness to pay) and economic (ability to pay) affordability (Sheth \& Sisodia, 2012). According to previous research, customers mostly purchase products based on price rather than other variables (Peter \& Donnelly, 2013). Price is the key determinant of the success of various products and services (Law et al., 2008), but it cannot achieve on its own. The customers need good quality products with a reasonable price. Affordability receive to the customer via satisfying their wants and needs (Peng \& Wang, 2006).

Economic affordability may have a strong impact on behavior (Jager, 2000; Ajzen, 2006). For example, Riefer and Hamm (2008) found changes in organic food consumption in relation to changes in the affordability. Economic affordability plays a significant positive role in explaining organic food purchases. Psychological affordability is usually related to perceived value and benefit. So, if the consumer perceives that organic food has value (e.g. egocentric values, such as health or pleasure) (Zanoli \& Naspetti, 2002) and benefits, they might be willing to pay a higher price (Tse, 2001; Shaharudin et al., 2010). Organic food purchases are largely connected to consumers' environmental concerns, concerns about food quality, and/or safety. Hence, willingness to pay for organic products can be a good antecedent of organic food purchase behavior (Krystallis \& Chryssohoidis, 2005).

Accessibility; is to what extent customers are able to easily purchase and use the products, and it has two dimensions: availability and convenience (Sheth \& Sisodia, 2012). In order for a product to be accessible, a distribution channel is an important tool in a marketing context. Hence, to reach each customer and meet their 
demands is important. Especially it is important for purchase staple goods. But even today in the numerous countries and cities, the farming areas for organic produce and the distribution channels are still limited. Therefore, if consumers want to get organic food, they must make an effort which can be challenging for consumers. This situation may lead to negative attitudes among consumers (Chen, 2007). Thøgersen and Zhou (2012) pointed out that low availability is one of the barriers for consumer purchase of organic food. Even though the consumers are motivated for purchasing organic products, low accessibility of the goods can be a big barrier for this purchase intention in daily life (Vermeir \& Verbeke, 2006). On the other hand, in countries with many organic food stores, high accessibility is the major contribution to a considerable organic market share (Thøgersen, 2010). Another proof of this was found by Aschemann (Aschemann et al., 2007): When supermarkets, which previously did not offer organic food, started offering organic food, sales increased.

Awareness; is defined as to what extent customers have information regarding the products. This information must convince consumers to try the product, and, if possible, to repurchase it. Brand awareness and product knowledge are dimensions of this concept (Sheth \& Sisodia, 2012). Awareness is a major factor in the marketing mix. As mentioned above, when customers become aware of a business and its products, they may be persuaded to try the products and probably be reminded to repurchase it (Nezakati et al., 2013).

The increase in the awareness of organic products contributed to the growth of the market for organic food (Yadav \& Pathak, 2016). Many studies that have investigated how consumers perceive the organic concept confirm this finding. The studies showed that purchase motives were ascribed to environmental and health awareness (Browne et al., 2000; Magnusson et al., 2001; Jones et al., 2001; Wier \& Calverley, 2002). In addition to this, people who have a high level of awareness regarding these issues tend to have a higher purchase intention towards organic foods than others (Tregear et al., 1994). Contrary to this, lack of knowledge or awareness about the organic product can be a purchasing barrier (Makatouni, 2002).

\section{METHODOLOGY}

The key aim of this study is to identify which of the 4A marketing mix elements (acceptability, accessibility, awareness and affordability) that have the highest effect on consumers' purchase intention towards organic food. Secondly, and based on the results and findings from this study, efforts are made to provide institutions and marketers with practical suggestions on how to facilitate this organic sector's rapidly growing sectors in a food industry. This study will assist to marketers or organizations to examine the opportunities that $4 \mathrm{~A}$ attribute affecting consumers' purchase intention of organic food.

In this study, the Analytical Hierarchy Process (AHP) of multi-criteria decisionmaking techniques is used. Because, in making a decision, the scale used is important. To be meaningful of this decision, it should be meaningful as intuitive and statistically. The rate scales, such AHP, provide reasonable compare. AHP is one of the widely used multi-criteria decisionmaking methods. This method was first 
presented by Saaty (1990). It provides a comparison of the considered options. By reducing complex decisions to a series of simple comparisons and rankings, and then by synthesizing the results, the AHP helps analysts to arrive at the best decision (Şengül \& Eren, 2015).

The theoretical framework for standard survey methods significantly differs with AHP applications. Particularly, standard survey methods require a sample size formula calculation based on an appropriate sampling technique to determine a minimum sample size from the entire population. However, such a calculation is not required to perform an AHP application (Quoting by Baramichai et.al, 2007). By the way, the subjective nature of the modeling process is considered as a constraint for AHP. In this case, Fuzzy AHP is generally a convenient method to eliminate this uncertainty and this implies that the methodology cannot guarantee "certainly right" decisions. Therefore, conclusions cannot be generalized for all countries and institutions. This paper performs a Fuzzy AHP method in a particular sample using experts' opinions.

In light of this information for this research method, have been reached to the experts who have experience about organic food study. Data were collected from 10 academics of Aarhus University's MAPP Centre (research on the development, marketing and distribution of foods and the societal impact of the food sector and value creation in the food sector for consumers, industry and society). Experts (a person who has special skill or knowledge in some particular field) are determined as individuals who have a $\mathrm{PhD}$ degree, lecturer and have published in high-indexed journals within the scope of marketing and organic food area. Survey questions were arranged according to Saaty's (1990) original scale method (Table 1) (Brunelli, 2014) and be answered by experts.

All stages of the analytic hierarchy process (Saaty \& Vargas, 2012) in line with the objective of the study were conducted incrementally. Excel was used to analyze the data. The obtained results and the steps are as follows:

\section{Step 1: Pairwise comparison}

For the matrix of pairwise elements:

$\left[\begin{array}{llll}C_{11} & C_{12} & C_{13} & C_{14} \\ C_{21} & C_{22} & C_{23} & C_{24} \\ C_{31} & C_{32} & C_{33} & C_{34} \\ C_{41} & C_{42} & C_{43} & C_{44}\end{array}\right]$

\section{Step 2: Normalization}

Sum the value in each column of the pairwise matrix:

$$
C_{i j}=\sum_{i=1}^{n} C_{i j}
$$

Table 1. Saaty's AHP Scale

\begin{tabular}{cl}
\hline Weight & Definition \\
\hline 1 & Indifference \\
3 & Moderate preference \\
5 & Strong preference \\
7 & Very strong or demonstrated preference \\
9 & Extreme preference \\
The value $2,4,6$ and 8 can be used to denote intermediary values \\
\hline
\end{tabular}


Table 2. Pairwise Comparison Matrix

\begin{tabular}{ccccc}
\hline & Acceptability & Accessibility & Awareness & Affordability \\
\hline Acceptability & 1 & 1,09 & 0,66 & 0,83 \\
Accessibility & 0,91 & 1 & 0,99 & 1,11 \\
Awareness & 1,51 & 1,01 & 1 & 0,92 \\
Affordability & 1,20 & 0,90 & 1,08 & 1 \\
Sum & 4,63 & 4,00 & 3,73 & 3,87 \\
\hline
\end{tabular}

Divide each element in the matrix by its column total to generate a normalized pairwise matrix:

$C_{i j}=\frac{C_{i j}}{\sum_{i=1}^{n} C_{i j}}\left[\begin{array}{llll}X_{11} & X_{12} & X_{13} & X_{14} \\ X_{21} & X_{22} & X_{23} & X_{24} \\ X_{31} & X_{32} & X_{33} & X_{34} \\ X_{41} & X_{42} & X_{43} & X_{44}\end{array}\right]$

Divide the sum of the normalized column of matrix by the number of criteria used (n) to generated weighted matrix:

$W_{i j}=\frac{\sum_{i=1}^{n} X_{i j}}{n} \quad\left[\begin{array}{l}W_{11} \\ W_{12} \\ W_{13} \\ W_{14}\end{array}\right]$

Step 3: Consistency Analysis

Three actions need to be taken in order to arrive at the consistency ratio; i) calculate the consistency measure, ii) calculate the consistency index (CI), iii) calculate the consistency ratio $(\mathrm{CI} / \mathrm{RI}$ where $\mathrm{RI}$ is a random index).

\section{i) Calculate the Consistency Measure}

Consistency vector is calculated by multiplying the pairwise matrix by the weights vector:

$$
\left[\begin{array}{llll}
C_{11} & C_{12} & C_{13} & C_{14} \\
C_{21} & C_{22} & C_{23} & C_{24} \\
C_{31} & C_{32} & C_{33} & C_{34} \\
C_{41} & C_{42} & C_{43} & C_{44}
\end{array}\right] *\left[\begin{array}{l}
W_{12} \\
W_{22} \\
W_{32} \\
W_{42}
\end{array}\right]=\left[\begin{array}{l}
C v_{12} \\
C v_{22} \\
C v_{32} \\
C v_{42}
\end{array}\right]
$$

Then it is accomplished by dividing the weighted sum vector with criterion weight:

Table 3. Normalized Matrix

\begin{tabular}{|c|c|c|c|c|c|}
\hline & Acceptability & Accessibility & Awareness & Affordability & Weight \\
\hline Acceptability & 0,22 & 0,27 & 0,18 & 0,21 & 0,22 \\
\hline Accessibility & 0,20 & 0,25 & 0,27 & 0,29 & 0,25 \\
\hline Awareness & 0,33 & 0,25 & 0,27 & 0,24 & 0,27 \\
\hline \multirow[t]{2}{*}{ Affordability } & 0,26 & 0,22 & 0,29 & 0,26 & 0,26 \\
\hline & & & & Sum & 1 \\
\hline
\end{tabular}

Table 4. Final Ranking and Weight ratio of $4 A$ 's

\begin{tabular}{ccc}
\hline Ranking & 4A's & Weight (\%) \\
\hline $\mathbf{1}$ & Awareness & 27 \\
$\mathbf{2}$ & Affordability & 26 \\
$\mathbf{3}$ & Accessibility & 25 \\
$\mathbf{4}$ & Acceptability & 22 \\
\hline
\end{tabular}




$$
\begin{aligned}
& C v_{11}=\frac{1}{W_{11}}\left[C_{11} W_{11}+C_{12} W_{21}+C_{13} W_{31}+C_{14} W_{41}\right] \\
& C v_{21}=\frac{1}{W_{21}}\left[C_{21} W_{11}+C_{22} W_{21}+C_{23} W_{31}+C_{24} W_{41}\right] \\
& C v_{31}=\frac{1}{W_{31}}\left[C_{31} W_{11}+C_{32} W_{21}+C_{33} W_{31}+C_{34} W_{41}\right] \\
& C v_{41}=\frac{1}{W_{41}}\left[C_{41} W_{11}+C_{42} W_{21}+C_{43} W_{31}+C_{44} W_{41}\right]
\end{aligned}
$$

\section{ii) Calculate the Consistency Index (CI)}

$\mathrm{CI}=\left(\lambda_{\max }-\mathrm{n}\right) /(\mathrm{n}-1)$ where $\lambda_{\max }$ is a maximum net value of the comparison matrix. The $\lambda_{\max }$ closer to the number $\mathrm{n}$, the consistency is smaller.

$\lambda$ is calculated by averaging the value of the Consistency Vector:

$\lambda=\sum_{i=1}^{n} C v_{i j}$

$$
C I=(4,03-4) / 3=0,01
$$

\section{iii) Calculate the Consistency Ratio}

$\mathrm{CR}=\mathrm{CI} / \mathrm{RI}$ ( $\mathrm{RI}$ is a random index) and in practice, a CR of 0,1 or below is considered acceptable (Wind \& Saaty, 1980).

For our model $\mathrm{n}=4$ and $\mathrm{RI}=0,90$
$\mathrm{CR}=0,01 / 0,90=0,01$

$\mathrm{CR}=0,01<0,1$ and this result show that our model is consistency.

\section{CONCLUSION}

The main objective of this paper is to determine the most influential factor among $4 \mathrm{~A}$ for a consumer purchase intention process using a Fuzzy AHP methodology. The result indicated that awareness is the most significant factor (27\%) affecting consumer purchase intention towards organic foods. Affordability is the second most important factor $(26 \%)$, accessibility is third $(25 \%)$ and acceptability is found as the last $(22 \%)$. As it can be seen, the weights are close to each other. This case illustrates that the importance degree of the variables is similar in terms of their impact on the intention to purchase an organic food.

The demand for organic food is determined by consumers' awareness of organic food. The organic foods market has become one of the rapidly growing sectors around the world, especially in the European Union. So, if people are not aware of organic foods, the growing market will be insignificant. Further, it will contribute the further growth of the market. It is believed

Table 5. Constructing a Weighted Matrix

\begin{tabular}{ccccccc}
\hline & Acceptability & Accessibility & Awareness & Affordability & $\begin{array}{c}\text { Weighted } \\
\text { Average }\end{array}$ & $\begin{array}{c}\text { Consistency } \\
\text { Measure }\end{array}$ \\
\hline Acceptability & 0,22 & 0,27 & 0,17 & 0,21 & 0,88 & 4,03 \\
Accessibility & 0,20 & 0,25 & 0,26 & 0,28 & 1,00 & 4,02 \\
Awareness & 0,33 & 0,25 & 0,27 & 0,23 & 1,09 & 4,03 \\
Affordability & 0,26 & 0,22 & 0,29 & 0,25 & 1,04 & 4,03 \\
\hline
\end{tabular}

Table 6. Saaty's Random Index

\begin{tabular}{lllllllllll}
\hline $\mathbf{n}$ & 1 & 2 & 3 & 4 & 5 & 6 & 7 & 8 & 9 & 10 \\
\hline $\mathbf{R I}$ & 0.00 & 0.00 & 0.58 & 0.90 & 1.12 & 1.24 & 1.32 & 1.41 & 1.45 & 1.49 \\
\hline
\end{tabular}


that when the consumers have more knowledge about their health, environmental protection and the organic product, they will be more likely to have a positive attitude and positive purchase intention towards organic foods.

People believe that organic foods are good for health, have high product safety and high quality. This belief is associated with a positive attitude towards buying organic food. But in order to reach these health benefits, organic food must be affordable. Also, products must be accessible and acceptable, but if they are not affordable, the purchase intention does not change a purchasing behavior. Supply conditions play a crucial role in the development of the organic market and in an increase on the intention to purchase an organic food. If consumers are able to find organic food in conventional supermarkets as well as farmers' markets and health food stores, this condition can trigger the intention to purchase organic foods.

In many studies, an initial information about sustainable products has been proven to be one of the most important factors in the purchase intention of these products. Customers must be informed about organic foods to achieve success with any given product or service offered. If they trust the information being obtained, and using this information they become more familiar with organic foods. Hence, knowledge can assist in increasing the purchase of organic foods.

In order to facilitate future growth of the organic market in the world, emphasis should be placed on low availability and high prices. Particularly, more intensive but also more low-cost distribution strategies should be adopted. Price and quality of organic foods should be better relative to their conventional counterparts. The increasing importance of health should motivate consumers to consume organic food. Hence, consumers must be informed about organic foods (i.e. by different campaigns). To raise the level of awareness among consumers, community-based social marketing tools must be used. In this way, the attention of the consumer may be drawn towards organic foods, and any suspicions of the natural content of organic foods may be reduced. Additionally, consumers generally prefer not only healthy but also environmentally sustainable food products. Hence, consumers must be convinced that organic food does not contain food additives or preservatives. Thus, organic foods' functional and psychological acceptability can be increased.

\section{Acknowledgement}

This research has been supported by The Scientific and Technological Research Council of Turkey (TÜBİTAK).

\section{References}

Ajzen, I. (1988). Attitudes, personality, and behavior. Chicago, USA: Dorsey Press.

Ajzen, I. (2006). Theory of Planned Behaviour-Diagram, available at: http://people.umass.edu/aizen/tpb.diag.html

Anderson, J., \& Billou, N. (2007). Serving the world's poor: innovation at the base of the economic pyramid. Journal of Business Strategy, 28 (2), 14-21.

Aschemann, J., Hamm, U., Naspetti, S., \& Zanoli, R. (2007). The organic market. Pp. 123-51 in W. Lockeretz (eds.), Organic farming: An international history, Wallingford, England: CABI.

Baramichai, M., Zimmers Jr, E. W., \& 


\title{
УТИЦАЈ 4А МАРКЕТИНГ МИКСА НА ТЕНДЕНЦИЈЕ КУПОВИНЕ ОРГАНСКЕ ХРАНЕ
}

\author{
Bahar Türk, Aysel Erciş
}

\section{Извод}

Начин исхране је један од главних фактора који воде ка здрављу људи. Конзументи генерално доносе одлуке које су повезане са њиховим дневним потребама и избоом хране. На тај начин, важно је одредити главне потенцијалне факторе који утичу на коначну одлуку. Ове варијабле, које су такође познате и као 4А микс (прихватљивост, прихватљивост цене, доступност и свесност), утичу на одлуке корисника у свим стадијумима процеса доношења одлуке око куповине. Намера о куповини заузима прво место на почетку овог процеса. Одређивање најутицајнијих варијабли на намере о куповини је круцијално и од помоћи за сваког стејкхолдера који се фокусира на привлачење крајњих корисника. Циљ ове студије је да омогући бољи увид у намере о куповини и да одреди који од 4А атрибута је нејефектнији код утицаја на куповину органских прехрамбених производа. У те сврхе, подаци су анализирани применом АХП методе. Подаци су сакупљени од десет експерата са МАПП Центра, Аархус универзитета. Резултати су показали да је најзначајнији од микса 4А елемента "свесност". Њега прате “прихватљивост цене”, “доступност” и на крају “прихватљивост” самог производа.

Кључне речи: 4А маркетинг микс, органска храна, аналитички хијерархијски процес - АХП

Marangos, C.A. (2007). Agile supply chain transformation matrix: an integrated tool for creating an agile enterprise. Supply Chain Management: An International Journal, 12 (5), 334-348.

Bredahl, L. (2001). Determinants of consumer attitudes and purchase intentions with regard to genetically modified foodresults of a cross-national survey. Journal of Consumer Policy, 24 (1), 23-61.

Browne, A.W., Harris, P.J., HofnyCollins, A.H., Pasiecznik, N., \& Wallace, R.R. (2000). Organic production and ethical trade: definition, practice and links. Food Policy, 25 (1), 69-89.

Brunelli, M. (2014). Introduction to the Analytic Hierarchy Process NY, USA: Springer.

Chen, M.F. (2007). Consumer attitudes and purchase intentions in relation to organic foods in Taiwan: Moderating effects of foodrelated personality traits. Food Quality and Preference, 18 (7), 1008-1021.

Conner, M., \& Sparks, P. (2005). Theory of planned behaviour and health behaviour. Predicting health behaviour, Chapter 5, 170222.

De Boer, J., Helms, M., \& Aiking, H. (2006). Protein consumption and sustainability: Diet diversity in EU-15. Ecological Economics, 59 (3), 267-274.

Dreezens, E., Martijn, C., Tenbült, P., Kok, G., \& de Vries, N.K. (2005). Food and the relation between values and attitude characteristics. Appetite, 45 (1), 40-46.

Furst, T., Connors, M., Bisogni, C.A., Sobal, J., \& Falk, L.W. (1996). Food choice: a conceptual model of the process. Appetite, 26 (3), 247-266.

Hansen, T. (2008). Consumer values, the 
theory of planned behaviour and online grocery shopping. International Journal of Consumer Studies, 32 (2), 128-137.

Hughner, R.S., McDonagh, P., Prothero, A., Shultz, C.J., \& Stanton, J. (2007). Who are organic food consumers? A compilation and review of why people purchase organic food. Journal of Consumer Behaviour, 6 (2-3), 94-110.

Jager, W. (2000). Modelling consumer behaviour. Doctoral Thesis, University of Groningen, Groningen.

Jones, P., Clarke-Hill, C., Shears, P., \& Hillier, D. (2001). Retailing organic foods. British Food Journal, 103 (5), 358-365.

Kamande, S., \& Jarhult, W. (2013). Reaching the mass market of the base of the pyramid-using the five A's concept. Master Thesis, Linnaeus University, Sweden.

Krystallis, A., \& Chryssohoidis, G. (2005). Consumers' willingness to pay for organic food: Factors that affect it and variation per organic product type. British Food Journal, 107 (5), 320-343.

Law, R., To, T., \& Goh, C. (2008). How do Mainland Chinese travelers choose restaurants in Hong Kong?: An exploratory study of individual visit scheme travelers and packaged travelers. International Journal of Hospitality Management, 27 (3), 346-354.

Magnusson, M.K., Arvola, A., Koivisto Hursti, U.K., Åberg, L., \& Sjödén, P.O. (2001). Attitudes towards organic foods among Swedish consumers. British Food Journal, 103 (3), 209-227.

Makatouni, A. (2002). What motivates consumers to buy organic food in the UK? Results from a qualitative study. British Food Journal, 104 (3/4/5), 345-352.

Nezakati, H., Aziz, Y.A., \& Zawawi, D. (2013). Preliminary Study of 4A Marketing Mix Impacts on Tourists' Satisfaction (Malaysian Food). Pp 371-378 in Global
Conference on Business and Economics Research.

Peng, L.Y., \& Wang, Q. (2006). Impact of relationship marketing tactics (RMTs) on switchers and stayers in a competitive service industry. Journal of Marketing Management, 22 (1-2), 25-59.

Peter, J.P., \& Donnelly, J.H. (2013). A preface to marketing management. NY, USA: McGraw-Hill.

Ploeger, A. (2009). Organic Food and Consumer Acceptance-Recommendations for Emerging Markets. Strategies (eg for regular users), 15 (25), 18-22.

Prahalad, C.K. (2009). The fortune at the bottom of the pyramid, revised and updated 5th anniversary edition: Eradicating poverty through profits. NJ, USA: FT Press.

Prahalad, C.K. (2012). Bottom of the Pyramid as a Source of Breakthrough Innovations. Journal of Product Innovation Management, 29 (1), 6-12.

Rezai, G., Mohamed, Z., \& Shamsudin, M.N. (2011). Malaysian consumer's perceptive towards purchasing organically produce vegetable. $\mathrm{Pp}$ 1774-1783 in 2nd International Conference on Business and Economic Research.

Riefer, A., \& Hamm, U. (2008). Changes in families' organic food consumption. Pp 16 in 12th Congress of the European Association of Agricultural Economists (EAAE).

Saaty, T.L. (1990). How to make a decision: the analytic hierarchy process. European Journal of Operational Research, 48 (1), 9-26.

Saaty, T.L., \& Vargas, L.G. (2012). Models, methods, concepts \& applications of the analytic hierarchy process. NY, USA: Springer.

Sarkar, D.N., \& Pareek, G. (2013). Rural marketing mix in Bhutan: An FMCG 
Perspective. Journal of Management Research, 12 (3), 7-28.

Şengül, Ü., \& Eren, M. (2015). Selection of digital marketing tools using fuzzy AHPfuzzy TOPSIS. Pp 97-126 in Fuzzy Optimization and Multi-Criteria Decision Making in Digital Marketing.

Shaharudin, M.R., Pani, J.J., Mansor, S.W., \& Elias, S.J. (2010). Factors affecting purchase intention of organic food in Malaysia's Kedah state. Cross-Cultural Communication, 6 (2), 105-116.

Sheth, J.N., \& Sisodia, R.S. (2012). The 4A's of marketing: creating value for customer, company and society, NY, USA: Rutledge.

Thøgersen, J. (2010). Country differences in sustainable consumption: The case of organic food. Journal of Macromarketing, 30 (2), 171-185.

Thøgersen, J., \& Zhou, Y. (2012). Chinese consumers' adoption of a 'green' innovationthe case of organic food. Journal of Marketing Management, 28 (3-4), 313-333.

Tregear, A., Dent, J.B., \& McGregor, M.J. (1994). The demand for organically grown produce. British Food Journal, 96 (4), 21-25.

Tse, A.C. (2001). How much more are consumers willing to pay for a higher level of service? A preliminary survey. Journal of Services Marketing, 15 (1), 11-17.

Türk, B., \& Erciş, A. (2015). Customer love: Research on the ranking of food and beverage locations. Management \& Marketing: Challenges for the Knowledge Society, 10 (2), 103-117.

Verdurme, A., \& Viaene, J. (2003). Consumer beliefs and attitude towards genetically modified food: basis for segmentation and implications for communication. Agribusiness, 19 (1), 91113.

Vermeir, I., \& Verbeke, W. (2006).
Sustainable food consumption: Exploring the consumer "attitude-behavioral intention" gap. Journal of Agricultural and Environmental Ethics, 19 (2), 169-194.

Vermeir, I., \& Verbeke, W. (2008). Sustainable food consumption among young adults in Belgium: Theory of planned behaviour and the role of confidence and values. Ecological Economics, 64 (3), 542553.

Weatherell, C., Tregear, A., \& Allinson, J. (2003). In search of the concerned consumer: UK public perceptions of food, farming and buying local. Journal of Rural Studies, 19 (2), 233-244.

Wier, M., \& Calverley, C. (2002). Market potential for organic foods in Europe. British Food Journal, 104 (1), 45-62.

Wind, Y., \& Saaty, T.L. (1980). Marketing applications of the analytic hierarchy process. Management Science, 26 (7), 641658.

Yadav, R., \& Pathak, G.S. (2016). Intention to purchase organic food among young consumers: Evidences from a developing nation. Appetite, 96, 122-128.

Yin, S., Wu, L., Du, L., \& Chen, M. (2010). Consumers' purchase intention of organic food in China. Journal of the Science of Food and Agriculture, 90 (8), 1361-1367.

Zanoli, R., \& Naspetti, S. (2002). Consumer motivations in the purchase of organic food: a means-end approach. British Food Journal, 104 (8), 643-653.

Zhen, J.S.S., \& Mansori, S. (2012). Young female motivations for purchase of organic food in Malaysia. International Journal of Contemporary Business Studies, 3 (5), 6172. 
